\title{
Disability as a Blind Spot in Sustainability Frameworks and Standards
}

\author{
Boris Miethlich
}

\begin{abstract}
After an accident or illness, returning to work can be difficult or even impossible. Although Occupational health and safety $(\mathrm{OHS})$ is an important and central element of Corporate social responsibility (CSR) and is included in all international CSR frameworks and standards as well as in most CSR strategies of companies, in the event that an employee becomes ill or has an accident and then needs support in returning to work or vocational rehabilitation, it is rarely a part of CSR strategies. Vocational rehabilitation as an element of CSR has also received little attention in the literature so far. The aim of this study is therefore to examine whether and to what extent vocational rehabilitation and also the employment of people with disabilities are taken into account in the popular CSR frameworks and standards. The research is based on a comprehensive search of published peer-reviewed literature. For the in-depth analysis, the most popular CSR frameworks, guidelines, firms' rating indices, management systems and certification schemes were selected and evaluated, using deductive content analysis. The results of the analysis show that although OHS is a central topic in all international CSR frameworks and standards, vocational rehabilitation and the employment of people with disabilities, or rather disability in general, are not taken into account. The conclusion suggests that the promotion of vocational rehabilitation and the employment of people with disabilities can be substantially promoted by implementation and consideration in CSR frameworks and standards. Irrespective of this, the implementation of vocational rehabilitation and the employment of people with disabilities as part of the CSR strategy and its implementation in business practice should be further investigated.
\end{abstract}

Index Terms: CSR, employment of people with disabilities, OHS, sustainability reporting, vocational rehabilitation.

\section{INTRODUCTION}

After an accident or serious illness, the return to work may become difficult or even impossible due to long incapacity to work or permanent impairment. Vocational rehabilitation enables persons with temporary, impending or permanent disabilities to access, return to or remain in a job [1]. Vocational rehabilitation is made up of medical and non-medical interventions that take place in parallel with the start of work and enable the gradual return to work with increasing recovery [2]-[3]. The terms vocational rehabilitation, return-to-work (RTW), disability management or operational case management are often used synonymously. The concepts are all aimed at reducing or preventing incapacity to work as a result of accidents and illness within the company [4].

An impairment or disability does not necessarily have to

Revised Manuscript Received on October 25, 2019.

Boris Miethlich, Graduate School, IIC University of Technology, Phnom Penh, Kingdom of Cambodia. Email: boris.miethlich@ gmail.com have an effect on the exercise of the profession or on the workplace. There are people with disabilities who are not impaired in working life or at work. However, there are also impairments that force people to change jobs, occupations or give up gainful employment [5]. It is estimated that 10 to 20 per cent of the population in each country is affected by disability [6]. Despite all efforts (legal provisions, anti-discrimination, equal treatment, etc.), people with disabilities continue to be affected by unemployment at an above-average rate [7]. People with disabilities or long-term health conditions such as groups with other barriers to labour market entry or job retention are vulnerable groups [8]. These vulnerable labour market groups also represent a large and growing part of the population in many countries [9]. People with disabilities cannot simply be equated with other disadvantaged groups as part of diversity. Diversity management approaches are too limited here and cannot really promote equality and equal opportunities for people with disabilities [10]. The hurdle for the employment is not primarily "stigma" but the amount of mental and physical barriers within the company [11]-[12]. Frequently, individual adjustments to the workplace and working environment according to the disability or individual aids are necessary, but adjustments to the job profile [13] or the conditions, such as irregular, adjusted or flexible working hours, may also be necessary [14].

Vocational rehabilitation can be understood as a variant of employment for people with disabilities. However, it differs in a number of respects. It can be assumed, for example, that when a person with disabilities is regularly employed, the employee knows his or her abilities, knows what adjustments are required at the workplace or with aids and how these are best used. In the context of vocational rehabilitation, performance needs to be trained, increased and tested first: this takes some time due to progressive recovery and adaptation to the work process as well as testing optimal workplace adaptations. Vocational rehabilitation in companies is a limited period of several months. Following vocational rehabilitation, it is often necessary to clarify whether and to what extent the person concerned can continue to be employed in the company [15]. Various studies show that people who are employed in some form of work during the healing process recover almost twice as quickly as people who do not work. Returning to the company, even to a different or possibly adapted workplace, also enables the person concerned to continue to be formally and informally involved in the business [16]. Often, however, there are no suitable alternatives to work within the company and a person affected is dependent on being given a chance in another company despite any impairments [17]. 
Vocational rehabilitation, as a positive intervention to prolonged incapacity to work, can accelerate the return to work and thus minimize lost working days, increase the productivity of limited employees, reduce early retirement and generally contain social costs [16], [18].

Vocational rehabilitation was ratified as a separate standard by many states as early as 1983 by the International Labour Organization (ILO) Convention No. 159, which committed them to regularly revise legislation and provide access to appropriate measures for affected persons as well as to promote cooperation and coordination between governmental and private-sector organizations with regard to vocational rehabilitation [19]. Nevertheless, very few countries have a quota system or an obligation to employ people with disabilities or to participate in vocational rehabilitation [20]. Even in countries with extensive legal obligations, the process of vocational rehabilitation is often hampered by general problems and functions poorly. In addition, companies tend to barely fulfil their legal obligations in the rehabilitation process, as there are no sanctions to be feared [21]-[23]. In vocational rehabilitation, companies always find themselves in a field of tension between assuming social responsibility and fulfilling operational goals [24]-[25]. Although the social security and social insurance systems have many possibilities to support affected persons in their vocational rehabilitation, in the end they cannot be successful without the goodwill and commitment of companies. Vocational rehabilitation can therefore only really be promoted by the companies themselves. It is therefore an exclusively voluntary social commitment of a company. Overall, vocational rehabilitation and the employment of people with disabilities are important social concerns that companies must address as part of their Corporate social responsibility (CSR) strategy [17]. Nevertheless, the promotion of vocational rehabilitation offers added value for a company's social responsibility. This commitment serves society and the company is thus regarded as a good corporate citizen. It also generates an actual "shared value", makes disability-friendly values explicit at the workplace [17], [26] and since the prosperity of the society is increased, will benefit the company in return [11], [27]. Engagement can also be seen as an indicator of a socially responsible and caring employer. This has a signal effect on employees and promotes psychological occupational safety, thus strengthening employees' resilience and reducing stress-related illnesses.

The concrete implementation of vocational rehabilitation as an initiative in a company's CSR strategy must go beyond the legal minimum and can take place, for example, by means of RTW policies, proactive initiation and coordination of the rehabilitation process, the adaptation of workplaces and work activities, the institutionalisation of sheltered workshops and a specialist department within the company. In particular, access for external persons to the company's own soft workplaces, internships and entry positions is an increasingly important aspect, also because new forms of work (e.g. freelancers) increasingly lead to "work disability" due to lack of access to adequate vocational rehabilitation. The opening up of the company's internal vocational rehabilitation capacities to external persons can therefore make a significant positive contribution to social development [17].

Sustainability and CSR reporting can be used to measure and make transparent the sustainable development of a company. At the same time, companies are held accountable. CSR reporting is also becoming increasingly important for companies from a strategic point of view. The reporting serves internally as a basis for the further development and success testing of CSR activities and externally for informing stakeholders about CSR performance [28]-[29]. CSR reporting is an important instrument of CSR communication, i.e. of making socially responsible commitment visible and communicating it [28]. Awareness of CSR activities among customers, as well as among stakeholders in general, is a prerequisite for achieving benefits from it [30]-[31]. A reputation as a socially responsible company can generate additional competitive advantages [30]. The increasing relevance of corporate responsibility can also be seen at the political level, for example in the obligation of the European Commission to conduct CSR reporting for companies. Various international standards and frameworks exist for systematic and well-founded CSR reporting, which are used depending on the industry and strategic orientation. Due to the increasing political demand for transparency in companies, national and regional standards and frameworks are being developed in parallel with international ones [32]. CSR thus plays an important role in promoting Occupational health and safety (OHS). Today, CSR initiatives regarding OHS can be found in almost every company, and in most cases are far superior to the minimum requirements of national and international legislation for the protection of workers [33].

OHS is an essential part of a company's care for its employees and thus a central concern of CSR, and is accordingly considered in most CSR strategies of companies [33]-[36]. However, in the event that an employee becomes ill or has an accident and subsequently needs assistance in returning to work, is rarely part of CSR strategies [17]. OHS is concerned with the safety, health, and welfare of people at work. Its aim is to maintain the health of employees and to prevent illness and accidents. This is achieved through appropriate working and employment conditions, increased safety at the workplace and protection by environmental factors [37]. Vocational rehabilitation can theoretically be understood in a broader sense as an element of OHS [29], [35]. However, vocational rehabilitation of employees in corporate practice is not part of OHS. Even according to ILO standards, vocational rehabilitation is not part of OHS, even though the integration of vocational rehabilitation into ILO standards is discussed sporadically by the ILO themselves [37].

In recent years, interest in research on the implementation of CSR initiatives has increased sharply [38], but to date there is hardly any research on the implementation and adaptation of the employment of people with disabilities, vocational rehabilitation or closely related concepts as a part of the CSR strategy [24], [39]. Therefore, the aim of this study is to present and analyse the current situation of the representative international CSR frameworks and standards regarding the consideration of OHS, vocational 
rehabilitation and the employment of people with disabilities. The expected results are indications of whether these subjects are a concern of CSR frameworks and standards or not.

\section{METHODS}

The research is based on a comprehensive search of published peer-reviewed literature. For the in-depth analysis, the most popular international CSR frameworks, guidelines, firms' rating indices, management systems and certification schemes were selected and evaluated with regards to the consideration of OHS, vocational rehabilitation, the employment of people with disabilities and/or closely related concepts. The research was conducted using the deductive content analysis method according to Mayring [40]. The coding was carried out in accordance to the following categories: OHS, vocational rehabilitation and the employment of people with disabilities.

\section{RESULTS}

The most popular international CSR frameworks, guidelines, firms' rating indices, management systems and certification schemes [29], [32] were evaluated with regards to the consideration of OHS, vocational rehabilitation, the employment of people with disabilities and/or closely related concepts. CSR frameworks and standards that focus exclusively on environmental aspects were not considered (e.g. Environmental Management Systems ISO 14001, CDP Carbon Disclosure Project, TFCD Task Force on Climate-related Financial Disclosures, EMAS Eco-Management and Audit Scheme, Forest Stewardship Council, etc.). The results of the deductive content analysis can be seen in the table 1 . The analysis shows that OHS is an integral part of almost all CSR frameworks and management tools. Vocational rehabilitation or the employment of people with disabilities, on the other hand, is not taken into account.
Only the core labour standards of the ILO deal with vocational rehabilitation. It is astonishing that this standard dates from 1983. Otherwise, only "Social Accountability $8000 "$ refers directly and with a recommendation and "UN Global Compact (Communication on Progress)" refers indirectly and without recommendation to the corresponding ILO core labour standard. In the "OECD Guidelines for Multinational Enterprises", vocational rehabilitation is listed within the framework of "non-discrimination". It looks a little better for the employment of people with disabilities and is mentioned in the frameworks "Global Reporting Initiative (GRI Sustainability Reporting Standards)", "Organisation for Economic Co-operation and Development (OECD Guidelines for Multinational Enterprises)", "International Organization for Standardization (ISO 26000 Guidance on social responsibility)", "Guidance on Social Responsibility (ISO 26000:2010)" and "Social Accountability 8000". However, the employment of people with disabilities is not seen explicitly, but as part of non-discrimination, equal opportunities, employment of vulnerable groups and/or diversity. For example, individual needs such as adaptation of workplaces or accessibility are not further addressed. Only the core labour standards of the ILO and the "UN Global Compact (Communication on Progress)" explicitly deal with the employment of people with disabilities and any conditions or additional work associated with them. "Social Accountability 8000" merely refers directly and with a recommendation to this very ILO core labour standard. As a positive example, however, the "German Sustainability Code (DNK)", which unfortunately is not international but is widespread in Germany, can still be cited here. It explicitly deals with the employment of people with disabilities and lists any necessary individual adjustments to jobs that may be required.

Table- I: Results of the analysis of the popular CSR frameworks and standards

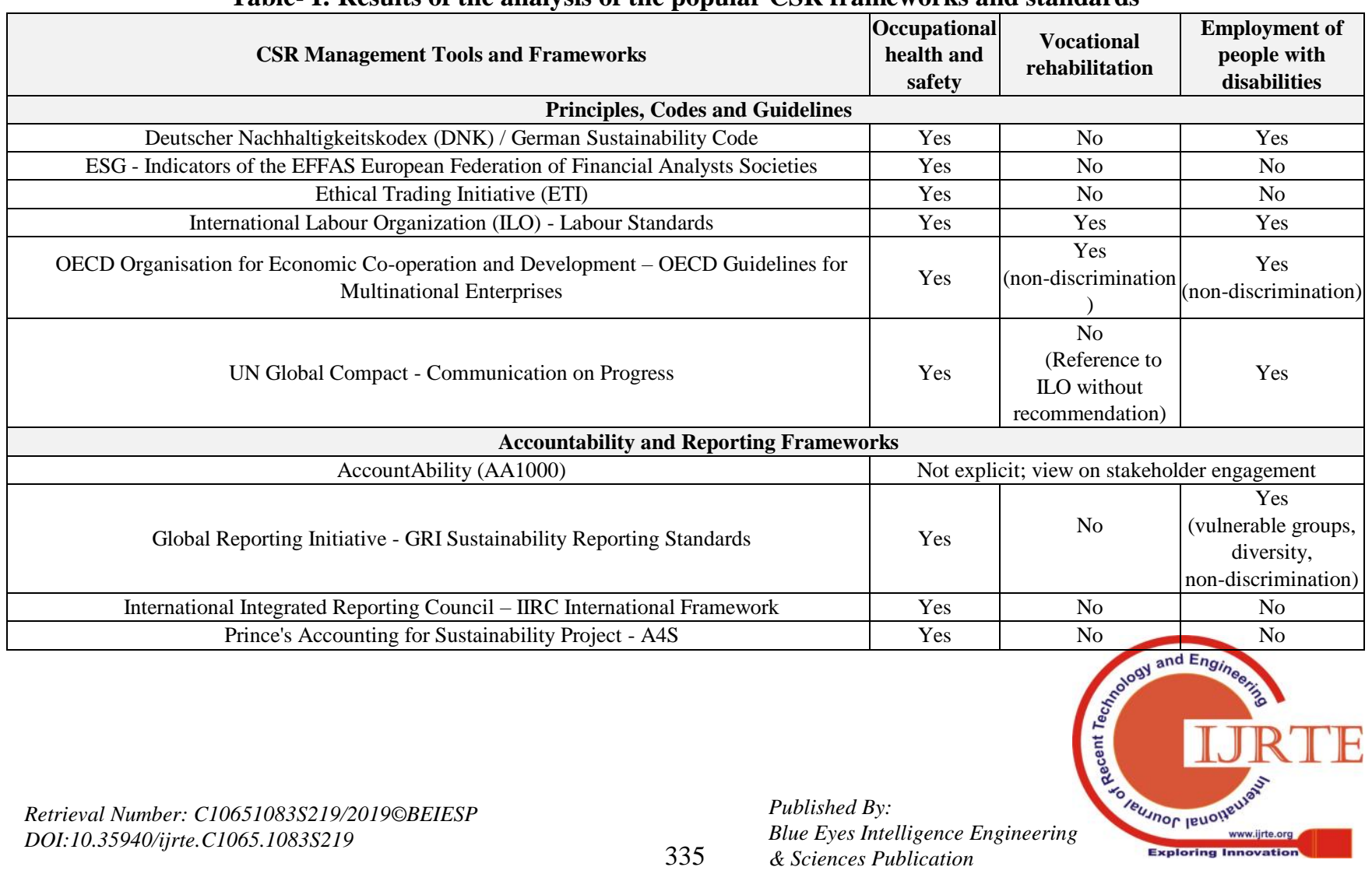




\begin{tabular}{|c|c|c|c|}
\hline Sustainability Accounting Standards Board - SASB & Yes & No & No \\
\hline \multicolumn{4}{|c|}{ Management Systems and Certification Schemes } \\
\hline $\begin{array}{l}\text { International Organization for Standardization - Guidance on Social Responsibility (ISO } \\
\qquad 26000: 2010)\end{array}$ & Yes & No & $\begin{array}{c}\text { Yes } \\
\text { (non-discrimination) }\end{array}$ \\
\hline Social Accountability 8000 & Yes & $\begin{array}{l}\text { Yes } \\
\text { (Reference to ILO } \\
\text { with } \\
\text { recommendation) }\end{array}$ & $\begin{array}{c}\text { Yes } \\
\text { (non-discrimination, } \\
\text { Reference to ILO } \\
\text { with } \\
\text { recommendation) }\end{array}$ \\
\hline Sustainability Integrated Guidelines for Management - SIGMA & Yes & No & No \\
\hline World Business Council for Sustainable development - CSR: making good business sense & Yes & No & No \\
\hline \multicolumn{4}{|l|}{ Firms' rating indices } \\
\hline Domini 400 Social Index & Not explicit & No & No \\
\hline Dow Jones Sustainability Group Index & Yes & No & No \\
\hline FTSE4Good Index Series & Yes & No & No \\
\hline
\end{tabular}

The results indicate that vocational rehabilitation and the employment of people with disabilities are not a concern of CSR frameworks and standards. OHS, on the other hand, is considered in almost all CSR frameworks and standards. The results of the study show, in accordance with the literature, that OHS is considered in virtually all international CSR frameworks and standards [41]. CSR plays an important role in the promotion of OHS [33] and should also be an effective instrument in the promotion of vocational rehabilitation and employment of people with disabilities [42]. The inclusion of vocational rehabilitation and the employment of people with disabilities in international CSR frameworks and standards may well promote this concern and improve the situation of those concerned. Also because this commitment would automatically become part of CSR reporting and a company would therefore have to account, albeit only indirectly, for the decision to engage in vocational rehabilitation and to employ or not to employ people with disabilities. Conversely, this does not mean that companies are not already involved in vocational rehabilitation or the employment of people with disabilities. Many companies commit themselves independently of a CSR strategy, but miss out of it the effective opportunity to gain competitive advantages through CSR [34].

The study reviewed the most important international CSR frameworks and standards. The reasons why certain criteria and aspects were or were not implemented in detail were not investigated. Nevertheless, the results of the study show that there is a discrepancy in perception. On one side, vocational rehabilitation and the employment of people with disabilities is an important social concern where there is a demonstrable need for action. On the other hand, these aspects are hardly considered in the international CSR frameworks and standards. Only speculations can be made about the reason for this, so it is possible that vocational rehabilitation can be regarded as an implicit part of OHS or as an exclusive task of the state. The employment of people with disabilities could also be implicitly regarded as part of non-discrimination, diversity or fundamental human rights and therefore not be given additional consideration. Also for these reasons, the concrete implementation of vocational rehabilitation as well as the employment of people with disabilities as part of the CSR strategy and its implementation in business practice must

\section{DISCUSSION}

be further investigated.

\section{CONCLUSION}

This study presented and analysed the current situation of the representative international CSR frameworks and standards regarding the consideration of OHS, vocational rehabilitation and the employment of people with disabilities. The results indicate that vocational rehabilitation and the employment of people with disabilities or rather disability in general are still not a concern of CSR frameworks and standards.

Disability continues to be a blind spot in sustainability frameworks and standards, so this concern is usually not mentioned in sustainability reporting of the most companies as well. With the consideration of disability in CSR frameworks and standards, this commitment would also automatically become part of CSR reporting and a company would thus have to account, albeit only indirectly, for the decision to become involved in vocational rehabilitation and to employ or not employ people with disabilities. OHS can be cited here as an exemplary example, which has experienced significant promotion, particularly through its inclusion in CSR frameworks and standards. Today, companies take OHS seriously as a social and societal concern and consistently take it into account in their CSR strategy. Irrespective of this, the implementation of vocational rehabilitation and the employment of people with disabilities as part of the CSR strategy and its implementation in business practice should also be further investigated.

\section{REFERENCES}

1. Waddell, G., Burton, A. K., \& Kendall, N. A. (2008). Vocational rehabilitation-what works, for whom, and when?(Report for the Vocational Rehabilitation Task Group). TSO.

2. Gobelet, C., \& Franchignoni, F. (2006). Vocational rehabilitation. In C. Gobelet \& F. Franchignoni (Eds.), Vocational rehabilitation (pp. 3-16) Springer.

3. Selander, J., Marnetoft, S. U., Bergroth, A., \& Ekholm, J. (2002). Return to work following vocational rehabilitation for neck, back and shoulder problems: risk factors reviewe. Disability and Rehabilitation, 24(14), 704-712.

4. Geisen, T., Lichtenauer, A., Roulin, C., \& Schielke, G. (2008) Disability Management in Unternehmen in der Schweiz. BBL.

5. Niehaus, M. (1997). Barrieren gegen die Beschäftigung langfristig arbeitsloser Behinderter. In $\mathrm{M}$. Niehaus \& L. Montada (Eds.), Behinderte auf dem Arbeitsmarkt (pp. 28-53). Campus Verlag. 
6. Collins, A. B. (2007). Opportunities and Obligations in Dealing with the Disabled Staff and Customers in Hospitality Industry. In P. R. Chang (Eds.), Tourism Management in the 21st Century (pp. 157-178). Nova Science Publishers, Inc.

7. Markel, K. S., \& Barclay, L. A. (2009). Addressing the Underemployment of Persons with Disabilities: Recommendations for Expanding Organizational Social Responsibility. Employee Responsibilities and Rights Journal, 21, 305-318.

8. Van Berkel, R., Ingold, J., McGurk, P., Boselie, P., \& Bredgaard, T. (2017). Editorial introduction: An introduction to employer engagement in the field of HRM. Blending social policy and HRM research in promoting vulnerable groups' labour market participation. Human Resource Management Journal, 27(4), 503-513.

9. Dean, A. (2013), Tackling Long-Term Unemployment Amongst Vulnerable Groups, OECD Local Economic and Employment Development (LEED) Working Papers, No. 2013/11, OECD Publishing, Paris.

10. Woodhams, C., \& Danieli, A. (2000). Disability and diversity - a difference too far?. Personnel Review, 29(3), 402-417.

11. Miethlich, B. \& Šlahor, L. (2018). Creating shared value through implementing vocational rehabilitation in the corporate social responsibility strategy: A literature review. 32nd IBIMA International Business Information Management Association Conference - Vision 2020: Sustainable Economic Development and Application of Innovation Management from Regional expansion to Global Growth (pp. 1444-1460). USA/King of Prussia: IBIMA Publishing.

12. Hidegh, A. L., \& Csillag, S. (2013). Toward 'mental accessibility': changing the mental obstacles that future Human Resource Management practitioners have about the employment of people with disabilities. Human Resource Development International, 16(1), 22-39.

13. Schur, L., Nishii, L., Adya, M., Kruse, D., Bruyère, S. M., \& Blanck, P. (2014). Accommodating Employees With and Without Disabilities. HR Science Forum, 53(4), 593-621.

14. Segovia-San-Juan, A. I., Saavedra, I., \& Fernandez-de-Tejada, V. (2017). Analyzing Disability in Socially Responsible Companies. Social Indicators Research, 130(2), 617-645.

15. Miethlich, B. (2018). Comparing the impact of employment of persons with disabilities and vocational rehabilitation on companies. 10th Biannual CER Comparative European Research Conference (pp. 43-47). London: Sciemcee Publishing.

16. Doucette, N. (2004). Modified Work Program: Why Bother?. In SPE International Conference on Health, Safety, and Environment in Oil and Gas Exploration and Production. Society of Petroleum Engineers.

17. Miethlich, B. \& Šlahor, L'. (2018). Employment of persons with disabilities as a corporate social responsibility initiative: Necessity and variants of implementation. 6th CBU International Conference on Innovations in Science and Education (pp. 350-355). Prague: CBU Research Institute.

18. Disler, P. B., \& Pallant, J. F. (2001). Vocational Rehabilitation Everybody gains if injured workers are helped back into work. $B M J$, 323(7305), 121-123.

19. ILO International Labour Organization. (1983). C159 - Vocational Rehabilitation and Employment (Disabled Persons) Convention No. 159. International Labour Office.

20. Morger, W. (2006). The point of view of the insurance company. In C. Gobelet \& F. Franchignoni (Eds.), Vocational rehabilitation (pp. 17-30). Springer.

21. Selander, J. (2016). Is Employer-Based Disability Management Necessary in a Social-Democratic Welfare State like Sweden?. International Journal of Disability Management, 11(4), 1-6.

22. Wiggett-Barnard, C., \& Swartz, L. (2012). What facilitates the entry of persons with disabilities into South African companies?. Disability and Rehabilitation, 34(12), 1016-1023.

23. Vilchinsky, N., \& Findler, L. (2004). Attitudes Toward Israel's Equal Rights for People With Disabilities Law: A Multiperspective Approach. Rehabilitation Psychology, 49(4), 309-316.

24. Seing, I., MacEachen, E., Ekberg, K., \& Ståhl, C. (2015). Return to work or job transition? Employer dilemmas in taking social responsibility for return to work in local workplace practice. Disability and rehabilitation, 37(19), 1760-1769.

25. Holmgren, K., \& Ivanoff, S. D. (2007). Supervisors' views on employer responsibility in the return to work process. A focus group study. Journal of occupational rehabilitation, 17(1), 93-106.

26. Millington, M. J., Miller, D. M., Asner-Self, K. K. and Linkowski, D. (2003), The business perspective on employers, disability, and vocational rehabilitation, Work and disability, Szymanski, E. and Parker, R. (ed), PRO-ED, Austin.
27. Papula, J., Papulová, Z. and Papula, J. (2014). Konkurenčné stratégie: tradičné prístupy vs. nové pohl'ady a techniky. Wolters Kluwer, Bratislava, Slovak Republic.

28. Moravcikova, K., Stefanikova, L., \& Rypakova, M. (2015). CSR reporting as an important tool of CSR communication. Procedia Economics and finance, 26, 332-338.

29. Koskela, M. (2014). Occupational health and safety in corporate social responsibility reports. Safety Science, 68, 294-308.

30. Peloza, J., \& Shang, J. (2011). How can corporate social responsibility activities create value for stakeholders? A systematic review. Journal of the academy of Marketing Science, 39(1), 117-135.

31. Sen, S., Bhattacharya, C. B., \& Korschun, D. (2006). The role of corporate social responsibility in strengthening multiple stakeholder relationships: A field experiment. Journal of the Academy of Marketing science, 34(2), 158-166.

32. BMAS. (2019). CSR - Unternehmen - Standards Der CSR-Berichterstattung. www.bmas.de. Retrieved November 8, 2019, from https://www.csr-in-deutschland.de/DE/Unternehmen/CSRBerichterstattung/Standards/standards-artikel.html

33. Dura, C. (2014). Occupational health and safety integration in corporate social responsibility policies within BRD-GSG Romania. Annals of the University of Petroșani, Economics, 14(2), 59-70.

34. Cierniak-Emerych, A., \& Zięba, K. (2014). Working conditions as one of the areas for implementing the concept of corporate social responsibility. Management, 18(1), 21-33.

35. Amponsah-Tawiah, K., \& Dartey-Baah, K. (2012). CSR-OHS: expert views, analysis and commentary on the two potent contrivances towards achieving MDGs. Journal of Global Responsibility, 3(2), 224-234.

36. Kornfeldová, M., \& Myšková, R. (2012). Health and Safety at Work Part of Corporate Social Responsibility. Scientific Papers of the University of Pardubice. Series D, Faculty of Economics \& Administration, 18(25), 90-99.

37. International Labour Conference. (2003). ILO Standards-related Activities in the Area of Occupational Safery and Health: An In-depth Study for Discussion with a View to the Elaboration of a Plan of Action for Such Activities: Report VI, Sixth Item on the Agenda. International Labour Office.

38. Wang, H., Tong, L., Takeuchi, R., \& George, G. (2016). Corporate social responsibility: An overview and new research directions thematic issue on corporate social responsibility. Academy of Management Journal, 59 (2), 534-544.

39. Monachino, M. S. and Moreira, P. (2014), Corporate social responsibility and health promotion debate: An international review on the potential role of corporations, International Journal of Healthcare Management, 7 (1), 53-59.

40. Mayring, P. (2015). Qualitative Inhaltsanalyse: Grundlagen und Techniken. Weinheim: Beltz, J.

41. Montero, M. J., Araque, R. A., \& Rey, J. M. (2009). Occupational health and safety in the framework of corporate social responsibility. Safety Science, 47(10), 1440-1445.

42. Csillag, S., \& Gyori, Z. (2016). "Is there a place for me?" - Employment of people with disabilities as part of CSR strategy. 2016 Strategica Conference: Opportunities and Risks in the Contemporary Business Environment (pp. 860-872). Bucharest: Tritonic.

\section{AUTHOR PROFILE}

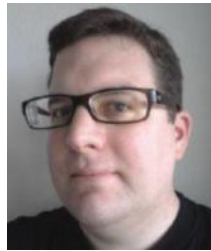

Boris Miethlich is a PhD student at IIC University of Technology, Cambodia. Before, he studied BSc Industrial Engineering and MSc Business Administration at the Swiss Distance University of Applied Sciences (SDUAS). His research focuses on the business potential of CSR and its exploitation. 